\title{
Runout of open pit slope failures: an update
}

\author{
J Whittall BGC Engineering Inc., Canada
}

A Mitchell The University of British Columbia, Canada

S McDougall The University of British Columbia, Canada

\begin{abstract}
A Fahrböschung angle versus volume methodology for estimating the runout distance of large open pit slope failures was proposed to the open pit geotechnics community in 2015 (Whittall et al. 2015). Since that 2015 publication, three commonly received questions on the methodology include:

1. How to estimate the runout of small, bench scale pit slope failures?

2. How to spatially distribute the runout estimate?

3. How to assess the risk to workers beyond an exclusion zone?

This paper provides a summary of refinements to runout estimate techniques for pit slope failures. In particular, empirical tools for estimating small-volume bench scale failures and a probabilistic framework for spatially distributed runout estimates are provided. A risk assessment methodology is proposed that can be mapped across the pit floor by dividing it into square grid cells and calculating individual risk for each cell. The goal of this paper is to supply practitioners with quick, repeatable tools to better understand the landslide risk to which workers and equipment are exposed, and support decision-making when working in an open pit with a developing or imminent pit slope failure.
\end{abstract}

Keywords: pit slope failure, runout analysis, exclusion zones, landslide risk management, trigger action response plans

\section{Introduction}

Mines commonly adopt an observational approach to continue working below deforming slopes. When to evacuate, and where to evacuate to, should be established prior to a slope accelerating and incorporated into the mine's trigger action response plan. Creating exclusion zones is a common response to reduce risk, however, uncertainty remains regarding how to best define these zones and what residual risk exists at these locations. A Fahrböschung angle versus volume methodology for estimating the two-dimensional runout distance of large open pit slope failures was proposed to the open pit geotechnics community in 2015 (Whittall et al. 2015). The tools presented were based on public domain data for failures ranging from 40,000 to 50 million $\mathrm{m}^{3}$. The application to smaller, more frequently occurring, failures had not yet been established. The recommended runout relationship provided a two-dimensional toolset in a probabilistic framework using prediction confidence intervals.

Since that 2015 publication, three commonly received questions on the methodology include:

1. How to estimate the runout of small, bench scale pit slope failures?

2. How to spatially distribute the runout estimate?

3. How to assess the risk to workers beyond an exclusion zone?

This paper provides an update to the two-dimensional, large pit slope failure runout relationships provided in Whittall et al. (2015), and expands the concepts to include bench scale and spatially distributed runout estimates that can be implemented in a risk management framework. 


\section{$2 \quad$ Background}

\subsection{Estimating risk to workers below a deforming slope}

Risk-based decision-making has been widely applied to the management of natural landslides (e.g. Bunce \& Martin 2011; Porter \& Morgenstern 2013; Macciotta et al. 2016) and increasingly for open pit slope failures (e.g. Whittall et al. 2017b). Landslide risk for either natural or excavated slopes can be calculated based on the following general equation:

$$
\text { Risk }=\sum_{i=1}^{n} P(H)_{i} \times P(S \mid H)_{i} x P(T \mid S)_{i} x V_{i} \times E_{i}
$$

where:

$$
\begin{aligned}
& i=\text { landslide scenario number (i.e. representing a landslide within a specific volume range). } \\
& P(H)_{i} \quad=\text { probability of the landslide occurring within a given time interval (note that annual } \\
& P(S / H)_{i}=\text { spatial probability that the landslide will reach the 'element at risk' (i.e. a specific piece } \\
& \text { of equipment or a person) if it occurs. } \\
& P(T / S)_{i}=\text { temporal probability that the element at risk will be present if the landslide reaches } \\
& \text { its location. } \\
& V_{i} \quad=\text { vulnerability (or probability of loss) if the element at risk is impacted. } \\
& E_{i}=\text { value of the element at risk (for economic risk calculations) or the number of people at } \\
& \text { risk (for life loss risk calculations). }
\end{aligned}
$$

Life loss risk can be expressed as either the risk to an individual (e.g. a single equipment operator) or a group (e.g. a number of equipment operators who may be present in the runout zone at the same time). Whittall et al. (2017b) provides a quantitative risk framework in which risk to individuals can be expressed as the probability of death of an individual within a given time interval, PDI, by setting the value of $E_{i}$ to 1 in Equation 1:

$$
P D I=\sum_{i=1}^{n} P(H)_{i} \times P(S \mid H)_{i} \times P(T \mid S)_{i} \times V_{i}
$$

The runout analysis tools described in the referenced papers are based on the observed behaviour of very rapid $(3 \mathrm{~m} / \mathrm{min}$ to $5 \mathrm{~m} / \mathrm{s}$ ) to extremely rapid $(>5 \mathrm{~m} / \mathrm{s}$ ) landslides (refer to Hungr et al. 2014 for landslide velocity class definitions). The first term on the right side of Equation 2 can, therefore, be broken down into two components as follows:

$$
P(H)_{i}=P(H) A_{i} \times P(H) B_{i}
$$

where:

$$
\begin{aligned}
& P(H) A_{i} \quad=\text { probability of a landslide of any velocity occurring within a given time interval. } \\
& P(H) B_{i} \quad=\text { probability that the resulting landslide is very rapid to extremely rapid. }
\end{aligned}
$$

The third term on the right side of Equation 2 can also be broken down to reflect the opportunity for early warning systems to reduce the risk:

$$
P(T \mid S)_{i}=P(T \mid S) A_{i} \times P(T \mid S) B_{i}
$$

where:

$$
\begin{aligned}
& P(T / S) A_{i}=\text { temporal probability that the worker is on duty when the landslide occurs. } \\
& P(T / S) B_{i}=\text { probability that the worker is not evacuated before the landslide reaches their location. }
\end{aligned}
$$


The full risk equation that forms the basis for the framework described in this paper is, therefore:

$$
P D I=\sum_{i=1}^{n} P(H) A_{i} \times P(H) B_{i} \times P(S \mid H)_{i} \times P(T \mid S) A_{i} \times P(T \mid S) B_{i} \times V_{i}
$$

Referring to Equation 5, the individual risk calculation is based on the following six questions:

1. $\boldsymbol{P}(\boldsymbol{H}) \boldsymbol{A}_{i}$ : What is the probability of a landslide within volume range $\mathrm{i}$ occurring within a given time interval?

2. $\boldsymbol{P}(\boldsymbol{H}) \boldsymbol{B}_{i}$ : If a landslide occurs, what it the probability it will be very rapid to extremely rapid?

3. $P(S \mid H)_{i}$ : If the landslide is very rapid to extremely rapid, what is the probability it will reach the equipment?

4. $P(T / S) A_{i:}$ If the landslide reaches the equipment, what is the probability the operator is on duty?

5. $P(T / S) B_{i}$ : If the operator is on duty, what is the probability they will not be evacuated before the landslide reaches the equipment?

6. $\boldsymbol{V}_{i}$ : If the operator is not evacuated in time (i.e. they are impacted), what is the probability they are killed?

Figure 1 is an event tree that illustrates the structure of Equation 5 and the corresponding questions summarised above. A detailed methodology and worked example for determining each term in Equation 5 is provided in Whittall et al. (2017b).

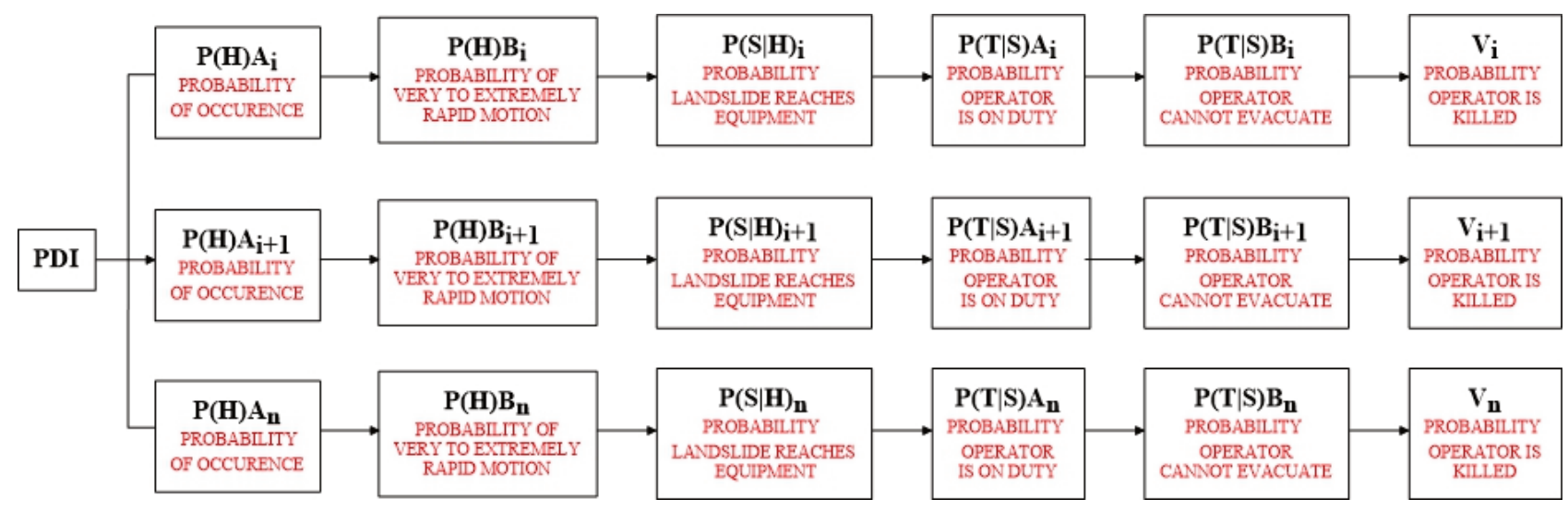

Figure 1 Open pit slope failure risk event tree

\subsection{Empirical runout relationships}

\subsubsection{Graphical relationships}

In the study of natural landslides, empirical runout methods are commonly used to assess the potential runout extent and inform hazard assessments. The earliest empirical runout relationship for landslides was developed by Heim (1932), who proposed that the distance a landslide will travel is proportional to its volume. He equated energy lost to work done, and postulated that the effective friction coefficient of sliding motion should be equal to the ratio of vertical to horizontal displacement. His Fahrböschung angle related volume of failed material to the ratio of fall height $(\mathrm{H})$ and horizontal runout distance $(\mathrm{L})$, to graphically describe the runout as the inclination of the line connecting the crest of the main scarp and the toe of the deposit (Figure 2). Whittall et al. (2017a) provide a summary of Fahrböschung angle and other empirical runout tools established for natural landslides. 


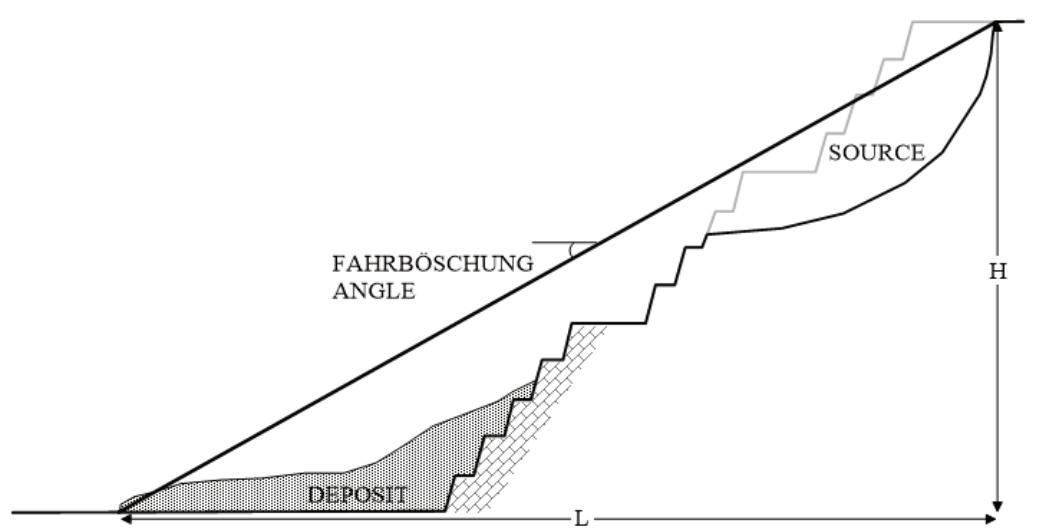

Figure 2 Schematic definition of the Fahrböschung angle

Hsü (1975) asserted that Heim's frictional approach appears true up to about $500,000 \mathrm{~m}^{3}$, then rock avalanches appear to flow more like liquids than a rigid mass sliding down an inclined plane. Other researchers (Scheidegger 1973; Ho et al. 2000; Hermanns et al. 2013) have postulated that, below a certain volume, Fahrböschung angle is insensitive to volume and the $\mathrm{H} / \mathrm{L}$ ratio is relatively constant, but not necessarily asserting that constant Fahrböschung angle is equivalent to the material's friction angle. Corominas (1996) describes a dataset in which both large and small landslides experienced travel distances in excess of what could be expected by equating Fahrböschung angle to friction.

The above-referenced researchers' definition of 'small' varied by 3.5 orders of magnitude and the variety of opinions demonstrates that volume is a long-questioned predictor of landslide mobility. Although the arguments differ, research agrees that volume itself is not a systematic indicator of mobility (Hsü 1975; Hungr 1990; Corominas 1996; Hungr et al. 2005). Rather, the lower Fahrböschung angle is more likely a result of scale effects. Finlay et al. (1999) hypothesised that at low volumes, other factors like slope geometry, geology, groundwater, and failure mechanism have more of an effect on runout than at larger volumes, as small landslides do not develop the large energy/momentum that overshadows these factors. In particular, to an open pit, small topographic irregularities like benches can be sheared by a large landslide but represent major obstacles to bench scale failures.

The previous empirical studies reviewed above have presented runout relationships in the form of log-linear regression lines, or power laws that linearise in log-log space. Examination of the data shows that there is a high degree of scatter around the fitted regression lines, especially when consideration is given to the fact that the data is linearised using a logarithmic transformation of both the regressor and predictor variables.

\subsubsection{Geographic information system and numerical tools}

Empirical relationships to estimate runout have been implemented in a geographic information system (GIS) environment to provide a preliminary characterisation of potential debris flow and rock avalanche runout scenarios (Griswold \& Iverson 2008; Horton et al. 2013; Mergili et al. 2015) using either cross-sections or plan area relationships. Several advanced numerical models have been developed for the purpose of predicting the runout of rock avalanches or other flow-like landslides (e.g. Hungr \& McDougall 2009; Christen et al. 2012, Mergili et al. 2017; Wang et al. 2017; Xu et al. 2019). These models are generally used for detailed assessments of potential events and there is generally insufficient data to build and calibrate one of these models for rapidly-developing failure scenarios. Recognising this limitation, Mitchell et al. (2019) developed linear regressions for travel distance and mean path width. The error distributions of those regressions were used to develop equations that can be used to make a probabilistic prediction of mobility, accounting for the variability in travel distance and impacted area directly with only topographic information required. The probabilistic equations are implemented in a GIS environment that provides a simplified representation of the spatial probability ranges of potential impacts. 


\subsection{Open pit slope failure datasets}

Large (Whittall et al. 2017a) and small (Whittall 2019) volume pit slope failure datasets have been developed for the application to runout estimate relationships. The large volume dataset is a compilation of 105 primarily public domain case histories ranging from 40,000 to 50,000,000 $\mathrm{m}^{3}$ collected from 63 mines. The small-volume dataset was developed by mapping failures, using digital elevation models (DEMs), ranging from 40 to $40,000 \mathrm{~m}^{3}$ at 15 mines from the first author's consulting practice. In both cases, the volume estimates are not bulked.

\subsection{Established open pit empirical runout relationships}

\subsubsection{Inter-ramp and overall slope scale}

Fahrböschung angle versus volume relationships (Figure 3) fit to large open pit slope failures provide reasonable runout estimates. The typical implementations of this relationship are to either draw a line in cross-section from the source crest at the selected Fahrböschung angle until it intersects the topography, or to place the apex of a cone at the centre of the scarp crest and fan the line segments at the Fahrböschung angle to the topography, creating a semi-circular exclusion zone. Two relationships are provided to reflect material behaviour differences in which failures with fresh, strong source materials result in shorter runout distances than those composed of weathered, weak source materials. Definitions of fresh, strong and weathered, weak source materials and a decision-matrix to help the user select the appropriate trend are provided in Whittall et al. (2017a).

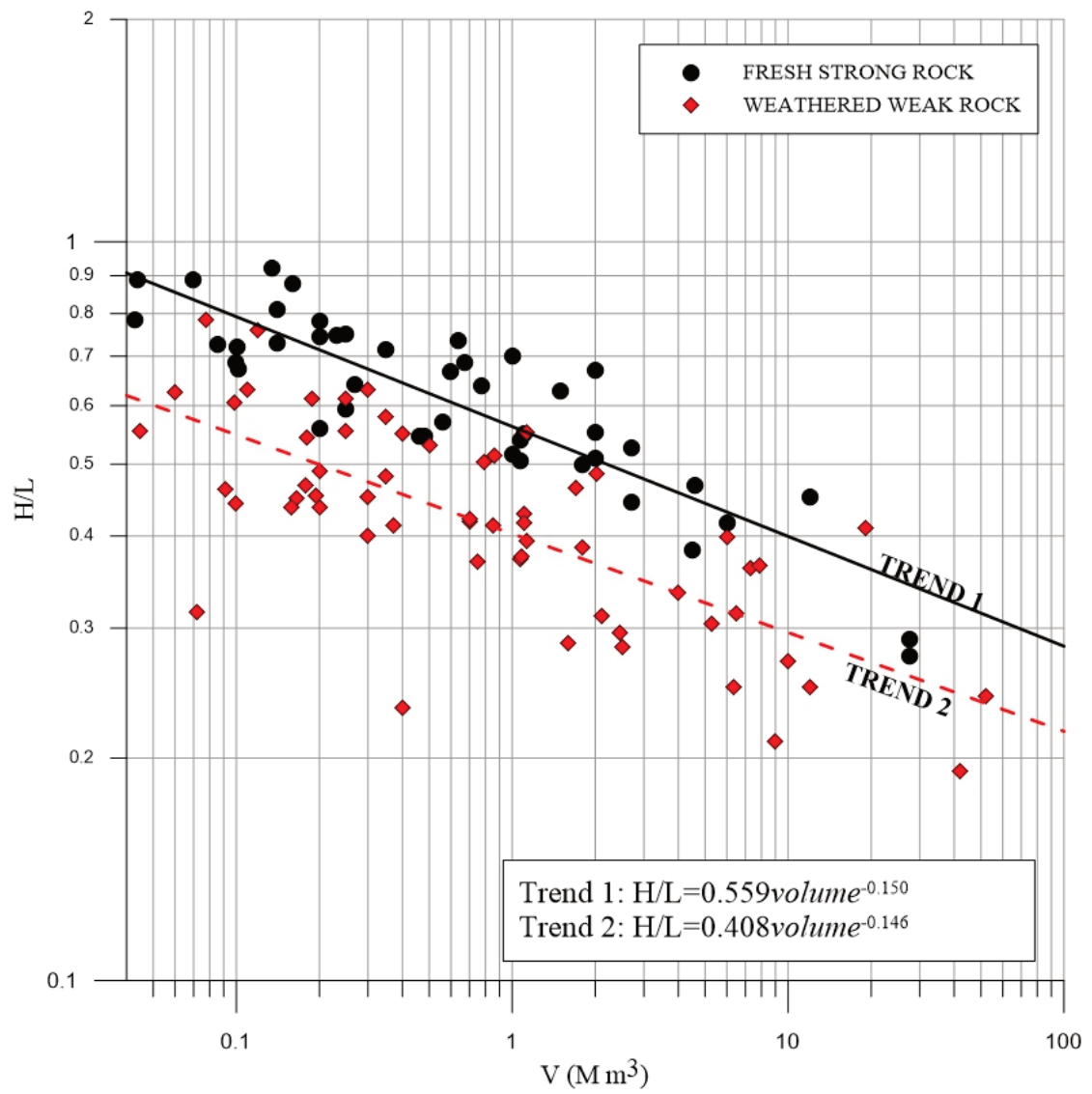

Figure 3 Fahrböschung angle versus volume relationship for large open pit slope failures

\subsubsection{Bench scale}

A runout length versus fall height (Figure 4) relationship has shown promising results for small-volume pit slope failures with fall height $<40 \mathrm{~m}$ (approximately two bench heights in the dataset analysed), and a 
Fahrböschung angle versus volume relationship (Figure 5) provided reasonably good runout estimates for the volume range analysed. The length versus height relationship may be favourable for failures one or two benches above the pit floor, where fall height can be easily estimated before the failure occurs. For cases where the deposited material is likely to drape over benches or ramps, it may be impractical to estimate the fall height in advance, and the Fahrböschung angle versus volume relationship may be favourable. As shown in Figure 5, the mobility of pit slope failures appears relatively insensitive to volume up to approximately $10,000 \mathrm{~m}^{3}$, after which it is inversely correlated.

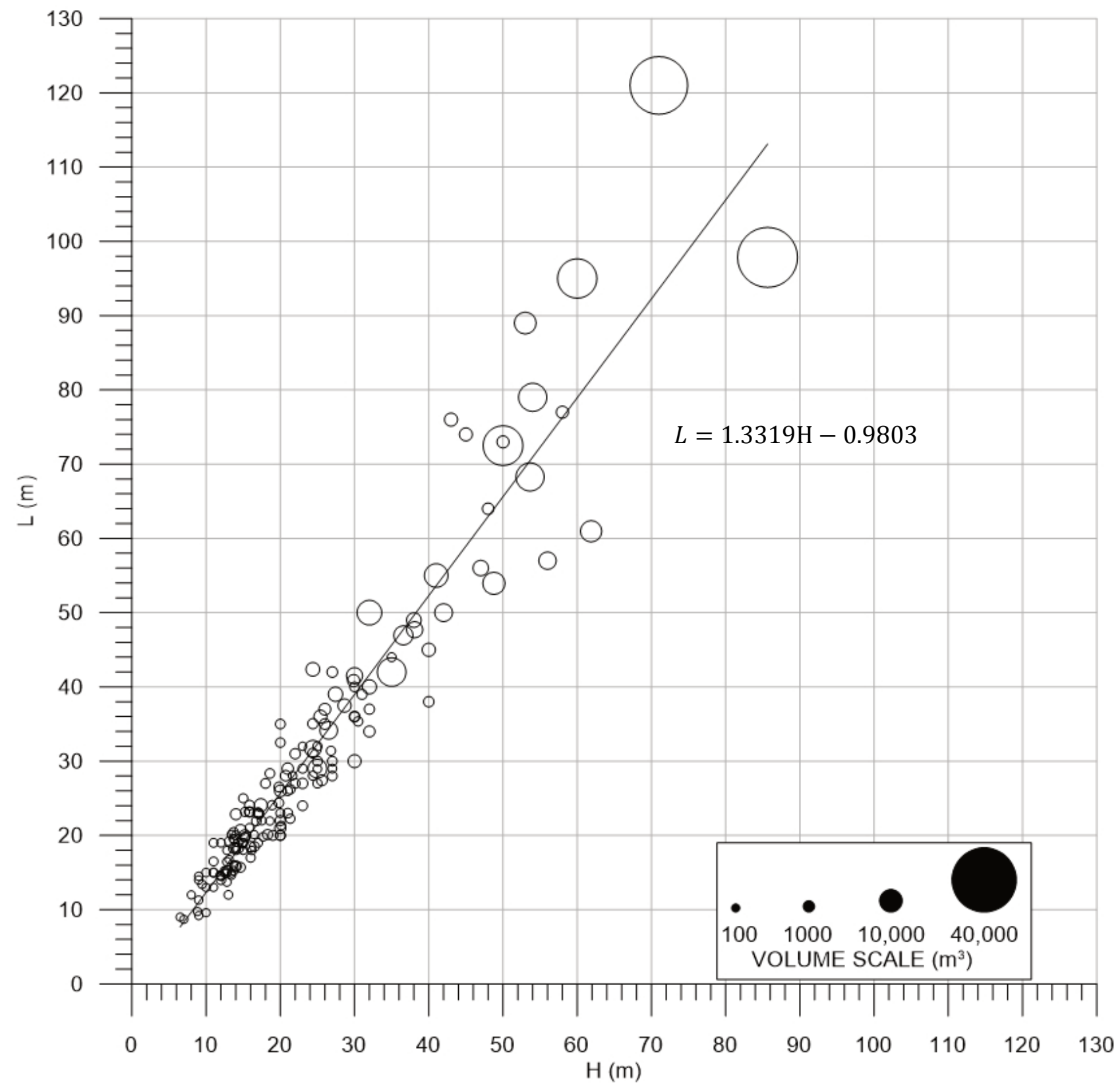

Figure 4 Runout length versus fall height relationship for bench scale pit slope failures 


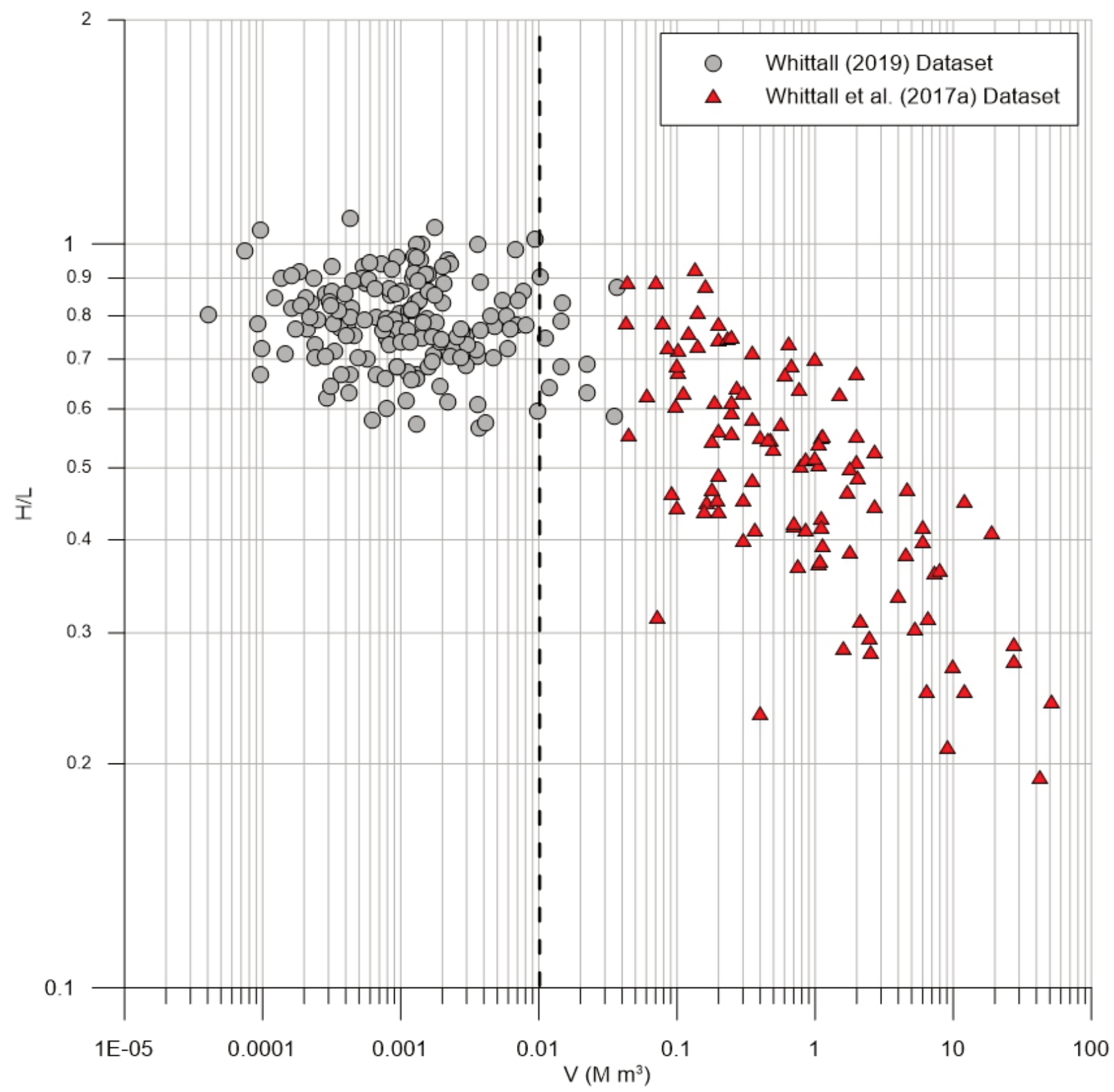

Figure 5 Fahrböschung angle versus volume plot

\section{Probabilistic runout estimates}

Fahrböschung-volume relationships have been commonly used for runout distance prediction, despite the debate around the physical validity of this approach (e.g. Legros 2002). Multiple linear regressions that treat the runout distance, fall height, volume, and other variables as independent predictors of runout have been increasingly used for natural landslide processes, such as natural rock avalanches (Zhan et al. 2017, Mitchell et al. 2019). Qualitative descriptors can be used in the analysis as indicator variables, where the indicator variable has a value of 1 if the descriptor is true for the case in question, otherwise it is 0 . This acts as an offset of the intercept of the regression, in other words, what is the difference from the mean? 
Following the methodology presented in Mitchell et al. (2019), a multiple linear regression was fit to the large open pit failure dataset. The following regression equation was found:

$$
\log L=0.734+0.189 \log V+0.827 \log H-0.062 C+\varepsilon
$$

where:

$$
\begin{aligned}
& \mathrm{L}, \mathrm{V}, \mathrm{H}=\text { defined previously. } \\
& C=\text { an indicator variable ( } 0 \text { or } 1) \text { for events that have a weak/weathered source geology } \\
& \text { (red), or strong/fresh (black), respectively. } \\
& \mathrm{E}=\text { the error term, assumed to be normally distributed with zero mean, } \varepsilon \sim N\left(0, \sigma^{2}\right) \text {. }
\end{aligned}
$$

$\mathrm{L}$ and $\mathrm{H}$ terms in Equation 6 are measured in metres, and $\mathrm{V}$ is in million cubic metres. The multiple linear regression can be represented as a $2 \mathrm{D}$ plot by transforming the log transformed variables back to natural numbers (Figure 6). Providing the large pit slope failure data in terms of length, rather than Fahrböschung angle, may be more easily applied when users are not using CAD to project angles or cones. Figure 6 and Equation 6 are most useful when assessing risk at a particular location. The $\mathrm{H}$ term will be the vertical distance from the scarp crest to the location of interest, and the length from scarp to location of interest can be compared to the $L$ term in Figure 6.

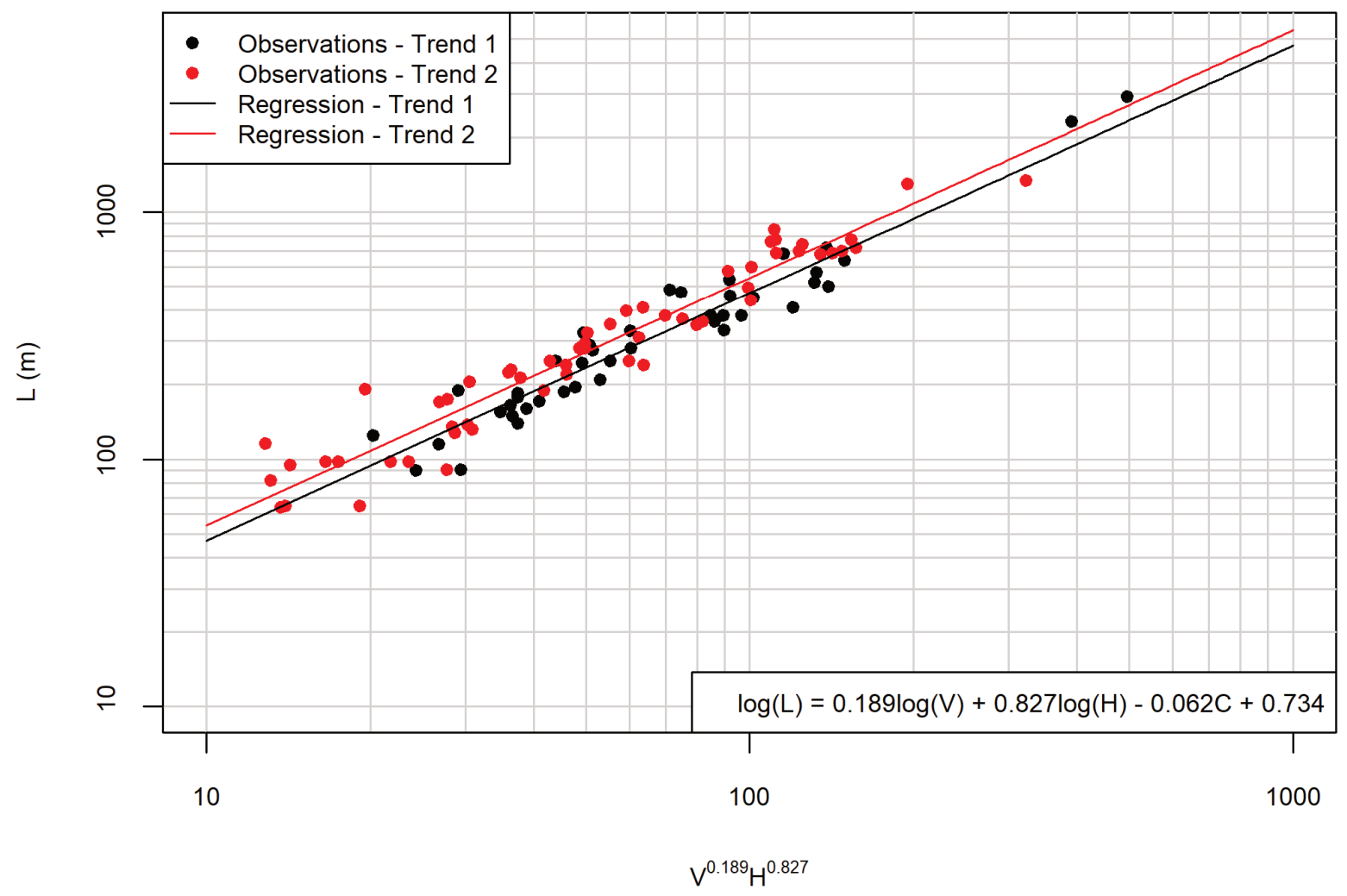

Figure 6 Relationship derived from multiple linear regression analysis for large open pit slope failures ( $H$ is in metres and $V$ is in million cubic metres)

\subsection{Survival functions}

Prediction confidence intervals have been used to set predictions based on empirical runout data into a probabilistic framework for natural rock avalanches (e.g. McDougall et al. 2012) and open pit slope failures (e.g. Whittall et al. 2017b). A more direct way of estimating the variability in predicted runout values is to make a survival function (sometimes referred to as a reliability function), which is one minus a cumulative distribution function. This is a commonly used statistical approach in other areas of engineering, such as manufacturing and medical studies. In qualitative terms, the survival function is the probability the realised 
runout length (L) will exceed a given length (I). The best-fit regression prediction for a given volume and fall height is equivalent to a $50 \%$ probability of exceedance, i.e. $P(L \geq \| \ldots)=0.5$. The use of a survival function to estimate the probability of runout exceedance for rock avalanches on natural slopes was demonstrated in Mitchell et al. (2019).

The regression equation shown in Equation 6, along with the distribution of error, can be rearranged into the following survival function:

$$
P(L \geq l \mid H=h, V=v, C=c)=1-\Phi\left(\frac{\log l-0.734-0.189 \log v-0.827 \log h-0.062 c}{0.090}\right), l>0
$$

where:

$$
\begin{aligned}
& l=\text { runout distance }(\mathrm{m}) . \\
& h=\text { fall height }(\mathrm{m}) . \\
& v=\text { volume }\left(\mathrm{M} \mathrm{m}^{3}\right) . \\
& \Phi=\text { the cumulative distribution function for a standard normal variable. }
\end{aligned}
$$

Survival function curves derived from the regression shown in Figure 6 can be seen in Figure 7. The curves shown span the volume and fall height range of the data used in developing the relationships.

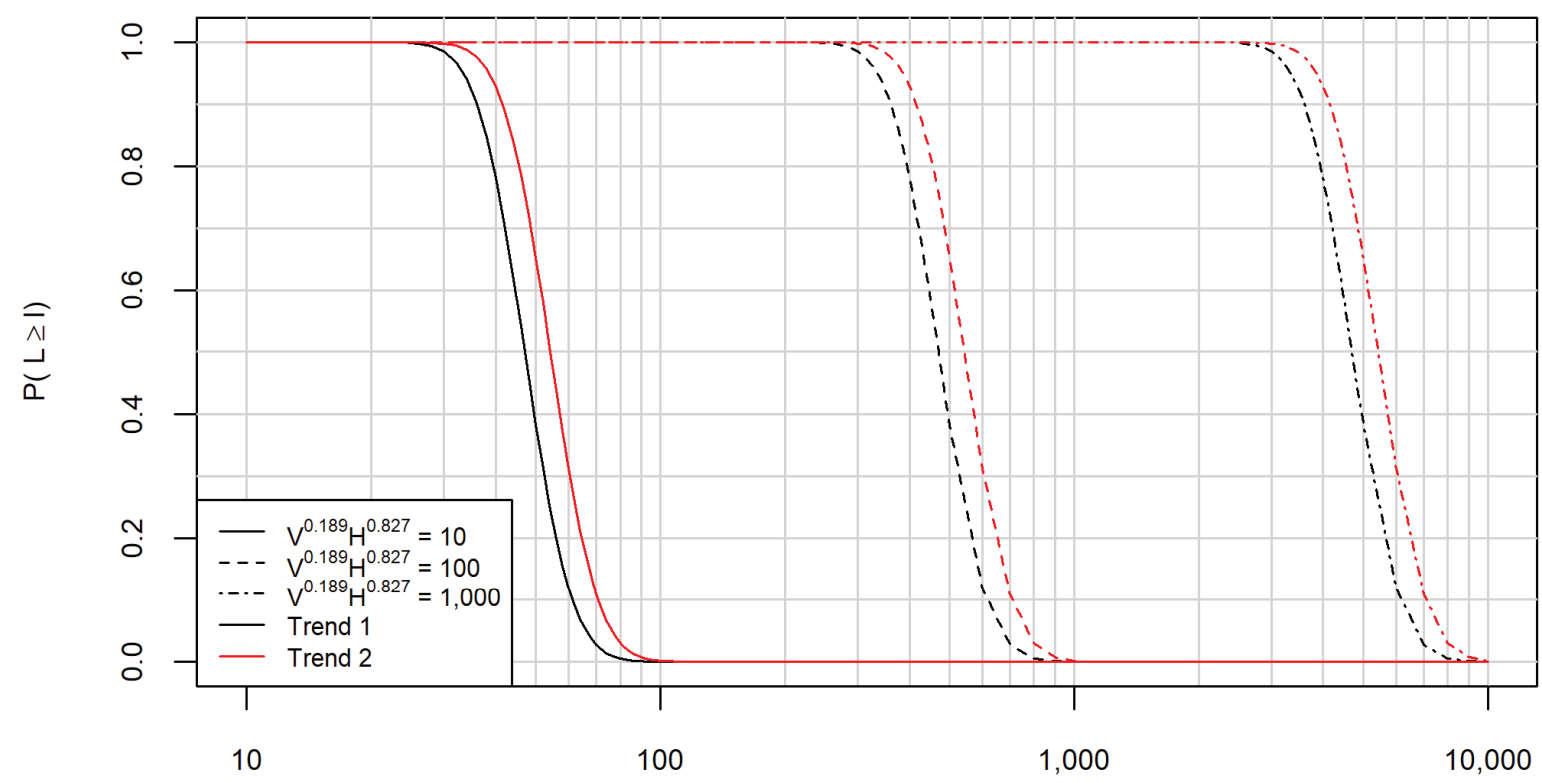

$L(m)$

Figure 7 Survival function curves derived from the multiple linear regression analysis for example input values $(H$ is in metres and $V$ is in cubic metres. Other values can be found through application of Equation 7 or interpolation of the curves shown

\subsection{Example probabilistic runout estimate}

A hypothetical example is shown to demonstrate the application of the survival function in Equation 7 to an open pit application. Considering a potential failure with its crest $100 \mathrm{~m}$ above the pit floor, and a volume of $0.1 \mathrm{M} \mathrm{m}^{3}$, with a weathered/weak source rock, the probability of the runout passing any distance along the pit floor can be calculated, as shown by the solid red line in Figure 8. If the mine operator had set as a criteria that no equipment and no personnel would be within a zone with greater than $10 \%$ probability of impact and $1 \%$ probability of impact, respectively, should a failure occur, exclusion distances can be read from the plot (200 $\mathrm{m}$ and $260 \mathrm{~m}$, respectively) and projected as a horizontal line from the source crest. 


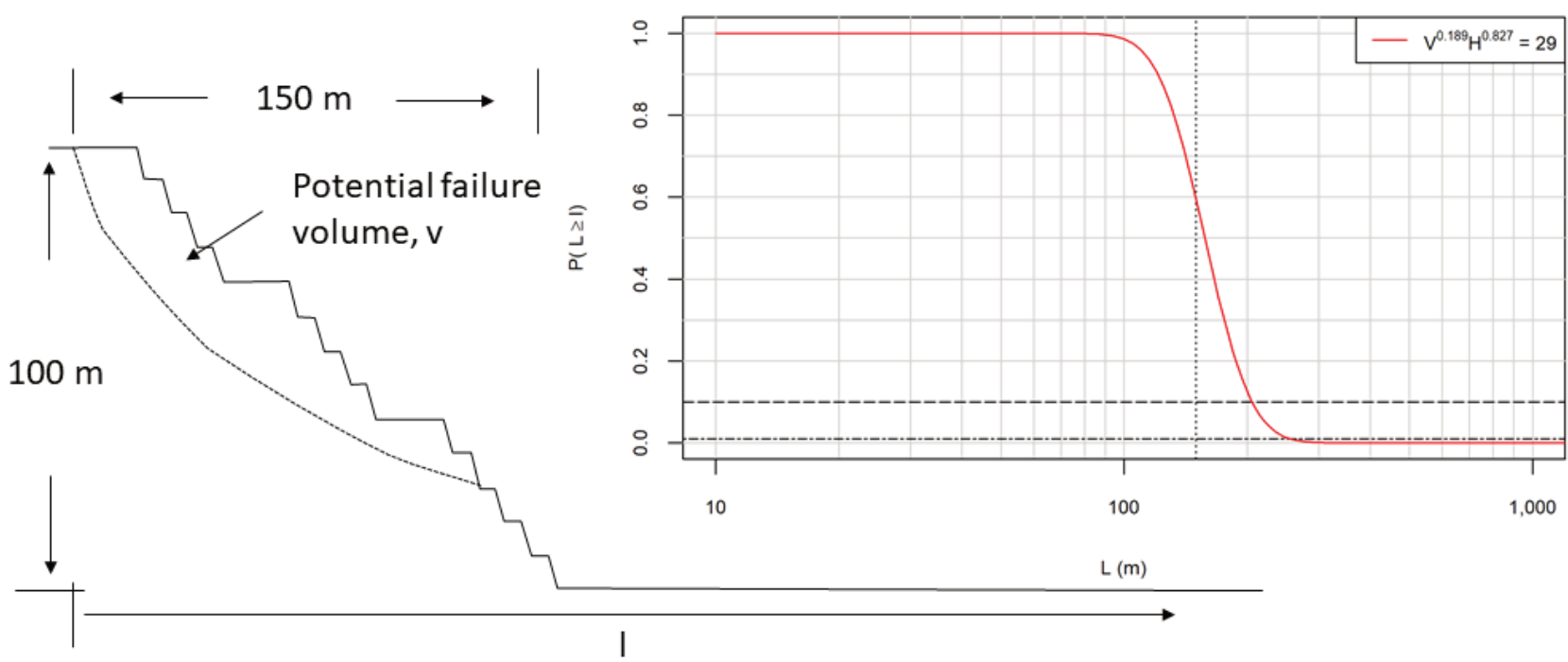

Figure 8 Example analysis showing the runout exceedance probability along a pit floor for a potential failure of $0.1 \mathrm{M} \mathrm{m}^{3}$. The dashed vertical line in the inset shows the distance to the pit floor, and the horizontal lines indicate the 0.1 and 0.01 probabilities

\section{$4 \quad$ Implementing a spatially distributed exclusion zone}

The preceding sections demonstrate the steps to estimate runout on a two-dimensional cross-section or path. In reality, equipment operating in an open pit moves around. It is, therefore, more useful to establish an exclusion zone by mapping risk across the pit floor. A proposed approach is to divide the pit floor into square grid cells and calculate the individual risk (PDI) for each cell using the steps described in Section 2 and Whittall et al. (2017b). The cells can be colour-coded to indicate specific PDI ranges and an exclusion zone can then be delineated based on a specified risk tolerance threshold (Figure 9). Delineating exclusion zones in terms of risk, rather than runout alone, forces the user to carefully consider the geology, hydrogeology, failure mechanism/s, monitoring information, runout potential, and operational workflows employed at the mine. Although it can create a slower decision-making process, the proposed framework unifies the geological, empirical, and operational information into a more robust decision. The PDI estimates can be updated regularly as new monitoring data become available and the extent of the exclusion zone can be modified accordingly.

Figure 9 Pit floor grid cells contoured based on PDI 


\section{Discussion of pit slope geometry}

The preceding paragraphs demonstrate the effects of a relatively small collection of attributes chosen for this paper, source volume and fall height because they have been observed to be the most influential on runout distance in the datasets analysed. The effects of overall slope angle, bench height, presence of and proximity to ramps, and proximity to the pit floor are discussed here to help practitioners apply the aforementioned relationships to their own pit configuration.

\subsection{Overall slope angle}

The relative influence of overall slope angle and source volume of pit slope failures was compared in Whittall et al. (2017a) showing a clear effect of the two parameters: they both contribute to the landslide's runout. The data for large pit slope failures showed steeper slopes having smaller failures with shorter runout distances. The typical geometry, with a constant slope angle of a pit wall abruptly changing to a flat pit bottom, is likely the cause. Abrupt path angle changes are an obstruction to the travel path and consume energy. Despite the relatively good correlation of the Fahrböschung angle versus original slope angle relationship shown in Whittall et al. 2017a, the volume-based approach is presented in this paper because it has a stronger physical basis, appears to be most popular with practitioners, and provides similarly accurate results.

\subsection{Proximity to ramps and the pit floor}

An interesting extension of these runout relationships is to assess whether $L$ changes if a given volume failure travels directly onto a flat surface such as a ramp or the pit floor versus if the travel path includes more benches. As discussed in the preceding paragraph, Whittall et al. (2017a) interpreted that large failures abruptly transitioning to a flat surface consume more energy, which reduces mobility. The same phenomenon is likely true for small-volume failures, however, the DEMs that form the basis of the small-volume failure assessment are often from well after the failures occurred, introducing uncertainty in the geometry of the travel path at the time of failure. Nonetheless, the $L$ versus $H$ relationship for bench scale failures may prove impractical when the travel path contains more benches or is likely to exceed the catchment of a ramp because $\mathrm{H}$ is more difficult to estimate before the failure. In the case that a bench scale failure is suspected to be large enough to exceed the catchment of a ramp, the Fahrböschung angle versus volume relationship in Figure 5 should be considered instead.

\subsection{Bench height}

The influence of bench height is strong for small-volume failures as it represents the majority of the fall height and nominal for large volume failures where a bench is a lesser proportion of the fall height. The height term in Figure 4 is the full height from source crest to deposit toe, rather than a function of bench configuration, to remove the complexity of a particular mines bench heights, berm widths, or double/triple benching. If fall height is normalised to the bench height (Figure 10), the positive correlation in Figure 4 is observed in terms of a homogenised bench height (i.e. length versus number of benches). The small population of larger volume cases separate from the scatter while the smaller, one or two bench high, cases appear similarly to Figure 4. A possible observation from this segregation is smaller failures are relatively unaffected by bench height and larger volume failures are more sensitive. Regardless, the suggested use of Figure 4 is for one or two bench high failures up to $40 \mathrm{~m}$ total height, which appear insensitive to the bench height. 


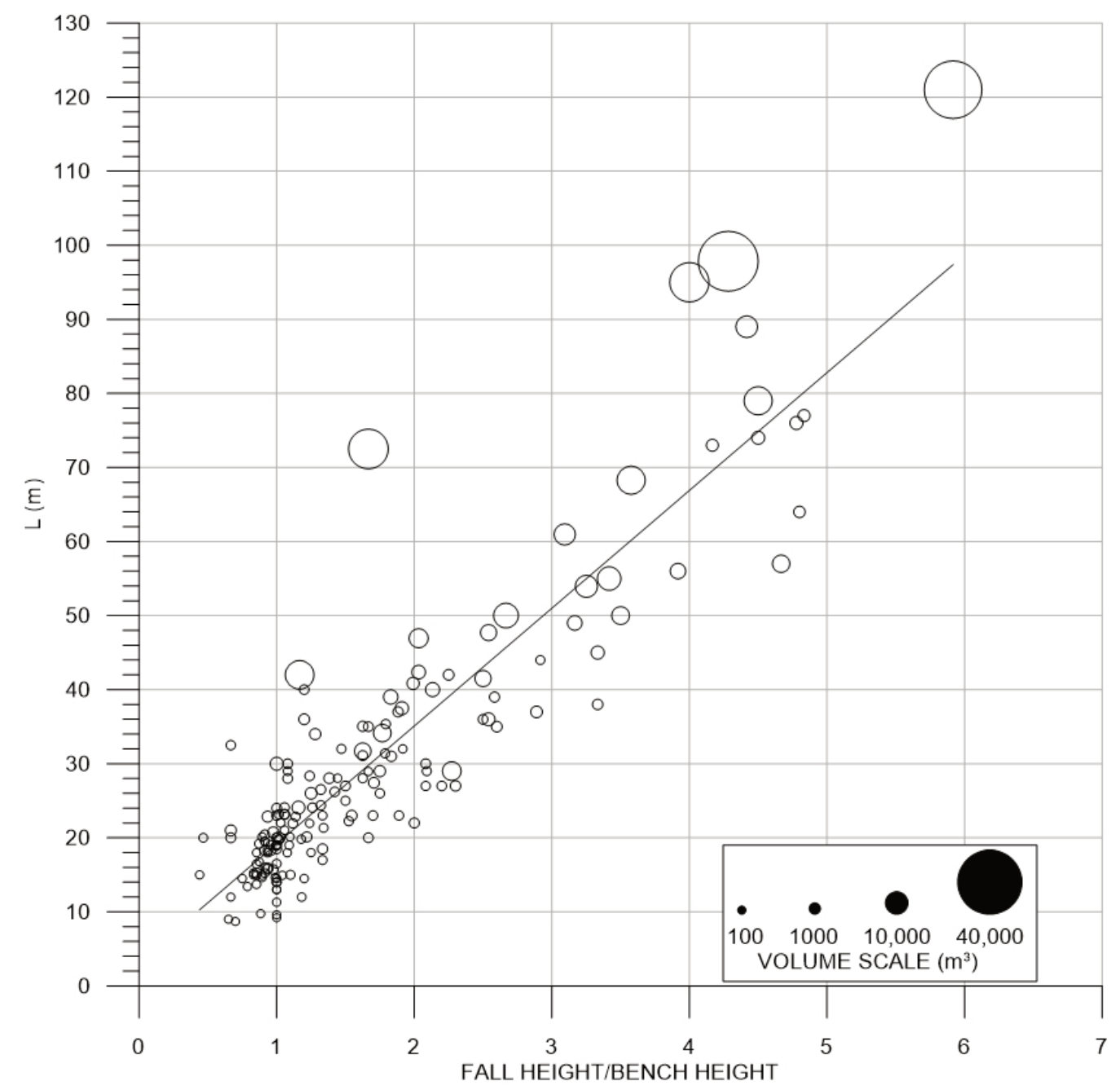

Figure 10 Runout length versus fall height normalised to bench height

\section{Conclusion}

This paper provides a synthesis of pit slope failure runout estimation tools developed since the original contribution in 2015. A runout length versus fall height relationship provides reasonably good runout estimates for failures one or two bench heights high above the pit floor. For larger volume failures, or failures where it is impractical to estimate fall height in advance, a Fahrböschung angle versus volume relationship calibrated to bench scale and large open pit slope failures provides a reasonable runout estimate.

Tools presented in this paper are geared to estimating runout at a particular location probabilistically, which can feed into a risk assessment. A multiple linear regression analysis was completed to relate the runout distance to the fall height and expected volume. A probabilistic prediction method derived from the multiple linear regression is provided in a graphical format, allowing the user to estimate the probability the failure will reach the work location. Finally, a procedure is proposed to establish spatially distributed exclusion zones by gridding the pit floor with an approximation of the risk imposed on the most exposed worker at each grid cell.

The goal of this work moving forward is to refine runout estimate techniques based on feedback from practitioners using these tools in operations. The nature of empirical tools is they can be continually improved with more data. Users are encouraged to test these relationships with their own case histories and continue to provide feedback to the authors. 


\section{References}

Bunce, C \& Martin, D 2011, 'Risk estimation for railways exposed to landslides', Proceedings of the 5th Canadian GeoHazards Conference, Canadian Geotechnical Society, Richmond.

Corominas, J 1996, 'The angle of reach as a mobility index for small and large landslides', Canadian Geotechnical Journal, vol. 33, issue 2, pp. 260-271.

Christen, M, Bühler, Y, Bartelt, P, Leine, R, Glover, J, Schweizer, A, ... \& Volkwein, A 2012, 'Integral hazard management using a unified software environment: numerical simulation tool "RAMMS" for gravitational natural hazards', in G Koboltschnig, J Hübl, J Braun (eds), Proceedings of the 12th Congress INTERPRAEVENT, International Research Society, Klagenfurt, pp. 77-86.

Finlay, PJ, Mostyn, GR \& Fell, R 1999, 'Landslide risk assessment: prediction of travel distance', Canadian Geotechnical Journal, vol. 36, issue 3, pp. 556-562, https://doi.org/10.1139/t99-012

Griswold, JP \& Iverson, RM 2008, Mobility statistics and automated hazard mapping for debris flows and rock avalanches, investigation report, U.S. Geological Survey, Reston.

Heim, A 1932, Bergstruz and Menchen leben (Landslides and human lives), BiTech Publishers, Vancouver.

Hermanns, RL, Oppikofer, T, Anda, E, Blikra, LH, Böhme, M, Bunkholt, H, C... \& Molina, FXY 2013, 'Hazard and risk classification for large unstable rock slopes in Norway', Italian Journal of Engineering Geology and Environment, pp. 245-254, https://doi.org/10.4408/IJEGE.2013-06.B-22

Ho, K, Leroi, E \& Roberds, B 2000, 'Quantitative risk assessment: application myths and future direction', Proceedings of the International Society Rock Mechanics International Symposium, CRC Press, Boca Raton.

Horton, P, Jaboyedoff, M, Rudaz, B \& Zimmermann, M 2013, 'Flow-R, a model for susceptibility mapping of debris flows and other gravitational hazards at a regional scale', Natural Hazards Earth System Sciences, vol. 13, pp. 869-885.

Hsü, KJ 1975, 'Catastrophic debris streams (sturzstroms) generated by rockfalls', Geological Society of America Bulletin, vol. 86, issue 1, pp. 129-140.

Hungr, O 1990, 'Mobility of rock avalanches', Report of the National Research Institute for Earth Science and Disaster Prevention, vol. 46, pp. $11-20$.

Hungr, O, Corominas, J \& Eberhardt, E 2005, 'Estimating landslide motion mechanism, travel distance and velocity', in O Hungr, R Fell, R Couture \& E Eberhardt (eds), Landslide Risk Management, Balkema, Vancouver. pp. 99-128.

Hungr, O \& McDougall, S 2009, 'Two numerical models for landslide dynamic analysis', Computers and Geosciences, vol. 35, pp. 978-992.

Hungr, O, Leroueil, S \& Picarelli, L 2014, 'The Varnes classification of landslide types, an update', Landslides, vol. 11, issue 2, pp. 167-194.

Legros, F 2002, 'The mobility of long-runout landslides', Engineering Geology, vol. 63, issue 3, pp. 301-331.

Macciotta, R, Martin, CD, Morgenstern, NR \& Cruden, DM 2016, 'Quantitative risk assessment of slope hazards along a section of railway in the Canadian Cordillera-a methodology considering the uncertainty in the results', Landslides, vol. 13, issue 1, 115-127, https://doi.org/10.1007/s10346-014-0551-4

McDougall, S, McKinnon, M \& Hungr, O 2012, 'Developments in landslide runout prediction', in JJ Clague \& D Stead (eds), Landslides: Types, Mechanisms and Modeling, Cambridge University Press, Cambridge, pp. 187-195.

Mergili, M, Krenn, J \& Chu, H-J 2015, 'r.randomwalk v1, a multi-functional conceptual tool for mass movement routing', Geoscientific Model Development, vol. 8, pp. 4027-4043.

Mergili, M, Fischer, J-T, Krenn, J \& Pudasaini, SP 2017, 'r.avaflow v1, an advanced open-source computational framework for the propagation and interaction of two-phase mass flows', Geoscientific Model Development, vol. 10, pp. 553-569.

Mitchell, A, McDougall, S, Nolde, N, Brideau, M-A, Whittall, J \& Aaron, J 2019, 'Rock avalanche runout prediction using stochastic analysis of a regional dataset', Landslides, https://doi.org/10.1007/s10346-019-01331-3

Porter, M \& Morgenstern, N 2013, Landslide risk evaluation-Canadian technical guidelines and best practices related to Landslides: a national initiative for loss reduction, open file 7312, Geological survey of Canada.

Scheidegger, AE 1973, 'On the prediction of the reach and velocity of catastrophic landslides', Rock Mechanics, vol. 5, issue 4, pp. 231-236, https://doi.org/10.1007/BF01301796

Wang, SN, Xu, WY, Shi, C \& Chen, HJ 2017, 'Run-out prediction and failure mechanism analysis of the Zhenggang deposit in southwestern China', Landslides, vol. 14, pp. 719-726.

Whittall, JR, Eberhardt, E, Hungr, O \& Stead, D 2015, 'Runout of open pit slope failures: using and abusing the Farboschung angle', Proceedings of the 2015 International Symposium on Slope Stability in Open Pit Mining and Civil Engineering, The Southern African Institute of Mining and Metallurgy, Johannesburg, pp. 99-112.

Whittall, JR, Eberhardt, E \& McDougall, S 2017a, 'Runout analysis and mobility observations for large open pit slope failures', Canadian Geotechnical Journal, vol. 54, pp. 373-391, https://doi.org/10.1139/cgj-2016-0255

Whittall, JR, McDougall, S \& Eberhardt, E 2017b, 'A risk-based methodology for establishing landslide exclusion zones in operating open pit mines', International Journal of Rock Mechanics and Mining Sciences, vol. 100, pp. 100-107, https://oi.org/10.1016/j.ijrmms.2017.10.012

Whittall, J 2019, 'Runout estimates and risk-informed decision making for bench scale open pit slope failures', Canadian Geotechnical Journal, vol. 0, no. ja, https://doi.org/10.1139/cgj-2018-0462

Xu, X, Jin, F, Sun, Q, Soga, K \& Zhou, GD 2019, 'Three-dimensional material point method modelling of the runout behaviour of the Hongshiyan landslide', Canadian Geotechnical Journal, vol. 56, no. 9, https://doi.org/10.1139/cgj-2017-0638

Zhan, W, Xuanmei, F, Huang, R, Pei, X, Xu, Q \& Weile, L 2017, Empirical prediction for travel distance of channelized rock avalanches in the Wenchuan earthquake area', Natural Hazards Earth System Sciences, vol. 17, pp. 833-844. 
